
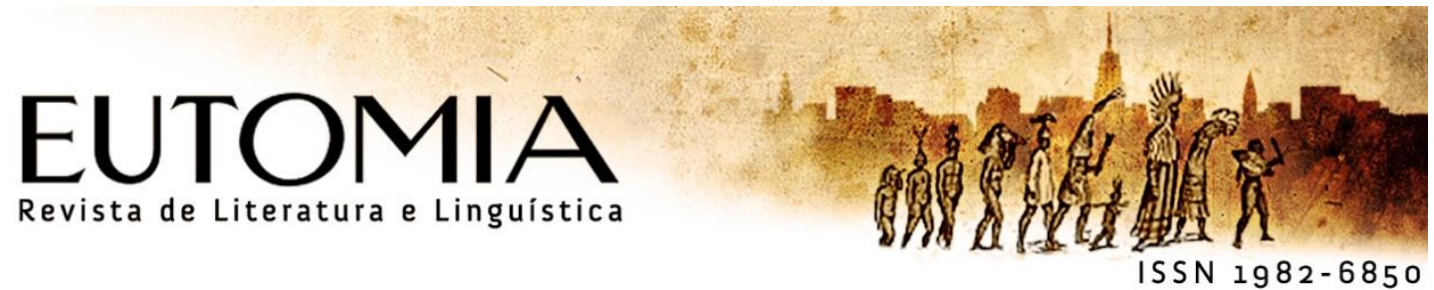

\title{
A ÉTICA NA LITERATURA - VIOLÊNCIA, JUSTIÇA, LITERATURA E SOCIEDADE: NA CRÔNICA "MINEIRINHO", DE CLARICE LISPECTOR.
}

\section{THE ETHICS IN LITERATURE - VIOLENCE, JUSTICE, LITERATURE AND SOCIETY: IN THE CHRONICLE "MINEIRINHO", BY CLARICE LISPECTOR}

\section{RESUMO:}

Ricardo Santos Davidi

O presente estudo aborda o texto "mineirinho", de Clarice Lispector, buscando a partir de ele depreender uma visão da constituição do sujeito à luz de alguns aspectos da psicanálise. A leitura analíticointerpretativa identifica os procedimentos estilísticos e temáticos que alicerçam o texto, desvendando suas implicações éticas e estéticas. Ao comentar a morte de um bandido pela polícia carioca nos anos 1960, a autora põe em xeque afirmações ideológicas tidas como inequívocas e subverte categorias políticas e sociais que se querem absolutas. No horizonte da interpretação proposta, o texto problematiza, ainda, as noções de normalidade e loucura, bem como as relações entre história social e trajetória individual.

Palavras - Chave: Clarice Lispector; literatura brasileira; ética; psicanálise; loucura.

\section{ABSTRACT:}

The present study approaches Clarice Lispector's "Mineirinho" text, seeking from it to understand a vision of the constitution of the subject in the light of some aspects of psychoanalysis. The analyticinterpretative reading identifies the stylistic and thematic procedures that underpin the text, revealing its ethical and aesthetic implications. In commenting on the death of a bandit by the Rio police in the 1960s, the author puts in question ideological statements considered as unequivocal and subverts political and social categories that are absolute. In the horizon of the proposed interpretation, the text also problematizes the notions of normality and madness, as well as the relations between social history and individual trajectory.

Keywords: Clarice Lispector; Brazilian literature; ethic; psychoanalysis; madness. 


\section{INTRODUÇÃO:}

A violência possui papel fundamental na história da humanidade. Ela ultrapassou os séculos com vários nomes e várias formas de interpretação, mas o fato é que destruiu civilizações e, ao mesmo tempo, construiu outras, pois sempre foi o instrumento mais eficaz de controle e dominação. Exemplos não faltam, temos as conquistas do Império Romano, a escravidão de negros e índios, e, sem nos afastarmos muito historicamente, a ditadura militar brasileira. Mas um fato curioso caminha linearmente: tudo isso aconteceu ao mesmo tempo em que se fortaleceu o discurso de superioridade da raça humana devido, principalmente, a nossa racionalidade, o que significaria que teríamos superados nossos instintos - que nos faziam primatas - e com a razão teríamos nos tornado seres civilizados. Então como pode ser assimilado que seres racionais tenham evoluído utilizando a violência característica instintiva - e continuarem com o seu status de civilizados? Contudo, dedicaremos a nossa sociedade ocidental capitalista com seus valores que assumiram múltiplos discursos para validar o interesse de alguns. No discurso religioso cristão, a violência possui, basicamente, duas interpretações: purificador e ato desumano. Como educativo, podemos lembrar do período da Santa Inquisição em que se queimavam mulheres para provocar o medo e assim conter as mudanças sociais. $E_{\text {, }}$ passado a Idade Média, com os adventos da modernidade, assume-se, no primeiro plano, o mandamento "Amai os outros como a ti mesmo". Podemos perceber que invoca a necessidade que o homem possui de viver em comunidade fazendo-o lembrar da relação eu e o outro. O amor também é importante nesse discurso, pois ele condiciona a forma de se relacionar; não será apenas por respeito, mas uma relação em que se reconheça no outro um irmão - amor como ágape. Só assim -

Religiosamente falando - compreendendo a comunidade como um núcleo familiar a violência seria banida. A distinção dualística entre homem e animal, civilizado e instinto, é outro discurso associado para a construção da sociedade. Neste caso, podemos ressaltar os estudos de Foucault em que ele demonstra a atuação do Biopoder. O desenvolvimento da medicina - incluindo aqui a psicanálise - construiu um discurso cuja violência, como representação, foi interpretada como um impulso 
natural de sobrevivência de todos os seres vivos. Mas não se podia assumi-la como necessária para os homens civilizados, pois esses lidariam não mais com seus instintos, eles teriam uma faculdade exclusiva - a razão. Opondo razão e instinto com a valorização do primeiro - se configura a ideia do "homem justo" como o ser superior da natureza, pois a violência é desarticulada das ações humanas, sendo condenada à condição de enfermidade. Destacando o discurso psicanalítico, a violência é aceita como constitutiva da natureza humana, mas é reformulada pelas necessidades civilizatórias. Assim, o homem saudável não é aquele que conserva suas características iniciais, mas sim aquele que consegue se controlar, que aceita os mecanismos sociais "de humanização". Os indivíduos que se utilizam da violência são vistos pela psicanálise como doentes e necessitam de tratamento específico para se inserirem na sociedade. Contudo, com esses e tantos outros discursos que purificam a raça humana da violência, por que mesmo assim ela sempre foi instrumento de fortalecimento e de imposição do poder? Esse é o tipo de pergunta que possuem várias e nenhuma resposta. Uma das melhores respostas é pensar que ela ainda é a forma mais eficaz de imposição de poder, ideias e ideais, uma vez que ela própria conseguiu se afirmar no campo da racionalidade. Pretendemos utilizar a crônica "Mineirinho", de Clarice Lispector, a fim de demonstrar como a violência se articula em discursos extremos para defender a propriedade.

Tanto ela pode ser vista como necessária, como ela pode ser rejeitada. O que vai depender será a articulação de dois elementos: necessidade com o medo. Inicialmente, é preciso contextualizar a crônica que será trabalhada. "Mineirinho" foi escrito paralelamente a repercussão que se desenvolveu na mídia brasileira sobre a execução de um assassino chamado Mineirinho. O fato chocou a opinião pública porque estavam envolvidos policiais que, sem misericórdia e rompendo com todos os direitos humanos e legais, o fuzilaram com treze tiros. A crônica começa mostrando que a função do intelectual diante do fato ocorrido é de investigar o grande mal-estar social, vejamos: "É, suponho que é em mim, como um dos representantes de nós, que devo procurar por que está doendo à morte de um facínora. E por que é que mais me adianta contar os treze tiros que mataram Mineirinho do que os seus crimes" (p.123). É válido ressaltar que Clarice Lispector pertence e representa certo grupo de 
intelectuais de classe média, então poderia se pensar que sua investigação só poderia se estender a esse campo social, mas a sensação que ela se propõe a descrever ultrapassa essa camada, de forma que, estrategicamente, ainda no primeiro parágrafo, a escritora escreve a conversa com a cozinheira; essa, atônita, responde: "O que eu sinto não serve para se dizer. Quem não sabe que Mineirinho era criminoso? Mas tenho certeza de que ele se salvou e já entrou no céu" (p.123). Dessa forma, criase a ideia de um sentimento que não é apenas de uma classe social, mas, é algo que corrói as entranhas sociais.

Mesmo as duas mulheres sendo de classes diferentes, podemos perceber que as duas compartilham da mesma fé: "Respondi-lhe que 'mais do que muita gente que não matou" (p.123). A diferença é que essa narradora-personagem - que se configura como sendo mulher, burguesa e que exerce a profissão de intelectual - se propõe a desmascarar o conteúdo religioso empregado no discurso conformista: "Por quê? No entanto a primeira lei, a que protege corpo e vidas insubstituíveis, é a de que não matarás. Ela é minha maior garantia: assim não me matam, porque eu não quero morrer, e assim não me deixam matar, porque ter matado será a escuridão para mim" (p.123). Esse desmembramento do discurso nos mostra em que está realmente focalizado no apelo de cunho religioso: no "eu-pessoal" e com a sua defesa no campo das relações sociais; e para comprovar o que afirmamos, de forma sucinta, destacamos os pronomes pessoais repetidos: "me" e "para mim", além do verbo querer conjugado na primeira pessoa.

Vejamos a descrição da sequência dos 13 tiros:

Esta é a lei. Mas há alguma coisa que, se me faz ouvir o primeiro e o segundo tiro como um alívio de segurança, no terceiro me deixa alerta, no quarto desassossegada, o quinto e o sexto me cobrem de vergonha, o sétimo e o oitavo eu ouço com o coração batendo de horror, no nono e no décimo minha boca está trêmula, no décimo primeiro digo em espanto o nome de Deus, no décimo segundo chamo meu irmão. $O$ décimo terceiro tiro me assassina - porque eu sou o outro. Porque eu quero ser o outro (p.123-124).

A obra de Clarice Lispector tem sido, desde a sua estreia com o romance perto do coração selvagem, em 1943, um constante desafio à crítica literária por vários motivos. 
O primeiro deles talvez seja a impossibilidade de classificá-la dentro de correntes ou parâmetros redutivos. A própria autora, segundo sua confidente Olga Borelli (1981, p.53), sentia-se totalmente isolada nas letras brasileiras; outra dificuldade está em seus textos recusarem interpretações excludentes, seja a abordagem existencial e metafísica, terreno ao qual desde sempre sua escritura foi identificada, seja a visada social e histórica dos estudos mais recentes. Tal cisão não faz jus ao que teima em ser dialeticamente íntegro.

Como enfrentar, então, um texto como "mineirinho", recolhido como crônica em 1969, mas que pode ser lido como conto, e que tenciona, a partir de uma ocorrência policial verídica, o sentido da justiça e as polaridades irredutíveis do eu e do outro? Será preciso mimetizar o estilo característico da autora, abarcando o texto de forma oblíqua, sugestiva, lacunar, evitando as noções conclusivas e absolutas. Porque ainda que a temática seja explicitamente social - a morte de um marginal carioca em 1962 em tiroteio com dezenas de policiais -, as reflexões do narrador extrapolam as contingências sociológicas e caminham, de forma errante e digressiva, pelos âmbitos mais recônditos da subjetividade. Por situar-se, portanto, nessa dupla face psicológica/existencial e ético/política -, "mineirinho" demanda um olhar abrangente, capaz de acompanhar sua múltipla significação. Tendo isso em vista, o propósito deste ensaio será desentranhar da estrutura narrativa - com seus recursos estilísticos, suas manobras de linguagem, seus elementos formais - uma gama de sentidos que aponte para o projeto ficcional da autora. o encontro desse texto particular com uma espécie de matriz constitutiva da visão de mundo da escritora é a miragem arriscada deste breve estudo, sabendo desde já que é o caminho que sobressai à meta pretendida; e que são bem mais palpáveis os fragmentos incompletos do que a totalidade almejada, essa sempre intangível e inapreensível, como nos mostrou Lispector por toda a obra.

No dia $1^{\circ}$ de maio de 1962 , sugestivamente a data comemorativa do "dia do trabalho", os jornais cariocas noticiavam a morte do assaltante mineirinho, apelido pelo qual era conhecido o fugitivo José Miranda rosa. Há dias procurado por mais de trezentos policiais, mineirinho havia escapado do manicômio judiciário e jurado nunca 
mais voltar ao cárcere para cumprir sua pena de 104 anos. Acuado pela polícia, acabou crivado de balas e seu corpo foi encontrado à margem da estrada Grajaú Jacarepaguá, no rio de janeiro. Para a análise da crônica em que Clarice Lispector comenta o episódio, vale a pena conferir como alguns jornais da época noticiaram a morte violenta de um dos bandidos mais temidos da região:

Com uma oração de santo Antônio no bolso e um recorte sobre seu último tiroteio com a polícia, o assaltante José Miranda rosa, "mineirinho", foi encontrado morto no sítio da serra, na estrada Grajaú Jacarepaguá, com três tiros nas costas, cinco no pescoço, dois no peito, um no braço esquerdo, outro na axila esquerda e o último na perna esquerda, que estava fraturada, dado à queima-roupa, como prova a calça chamuscada. (weguelin, s. d. diário carioca, $1^{\circ}$ de maio de 1962). A reportagem encontrou no local do tiroteio inúmeras cápsulas de balas calibre $45 \mathrm{~mm}$, usadas nas metralhadoras "thompson" e "ina", e um par de sapatos manchado de graxa. Acreditase que nesse tiroteio tenha sido morto o assaltante mineirinho. (ibidem) dezenas de pessoas pobres compareceram ao local onde foi encontrado o cadáver de mineirinho. Ninguém conseguiu aproximar-se do corpo, pois a polícia, por ordem do delegado Agnaldo amado do 23 dp, afastava todos com violência. Em geral, os moradores do morro se mostravam contrariados com a morte de mineirinho, que consideravam uma versão carioca de Robin Hood. (ibidem)

Treze vezes varado por disparos de metralhadoras "ina" e trajando blusão verde, calça preta e meias azuis, "mineirinho" foi jogado morto no capinzal existente a 5 metros do meio-fio do quilômetro 4 da estrada Grajaú Jacarepaguá. (weguelin, s. d. diário de notícias, $1^{\circ}$ de maio de 1962). Em volta do corpo não havia um único sinal de sangue, evidenciando que a morte não ocorrera naquele local. Além disso, os moradores do barraco das vizinhanças asseguraram que ali não se travara nenhum tiroteio durante a madrugada. "mineirinho" fora mesmo liquidado em outro lugar e removido para lá. (ibidem).Não foi a justiça quem decretou a morte do mais temível assaltante do rio de janeiro, conhecido pela alcunha de "mineirinho". Ele próprio a procurou, desafiando a tranquilidade pública e um aparelhamento policial cujas metralhadoras sabia não Ihe dariam trégua. Carregando 104 anos de prisão, o facínora 
ainda brincou pelas ruas e favelas da cidade durante dias, assaltando e baleando - que estas eram sua razão de viver. (weguelin, s. d. correio da manhã $1^{\circ}$ de maio de 1962). Nos jornais que noticiaram a morte, entre algumas manchetes, destacam-se títulos como: "'mineirinho' morreu com oração e recorte no bolso" (diário carioca); "'mineirinho' foi metralhado 13 vezes e atirado no mato - povo afluiu para ver bandido morto" (diário de noticias); "a cidade está em paz" (correio da manhã) e "'mineirinho' sem sete vidas" (jornal do Brasil).

Esse pequeno inventário da repercussão da morte de mineirinho não deixa dúvidas quanto à mobilização da opinião pública ante o caso, oscilando entre, de um lado, a possível "paz" que a eliminação do criminoso teria trazido ao rio de janeiro (conforme um dos títulos citados) e, de outro, a revolta dos moradores da favela com a morte de seu "Robin Hood". Fica claro, também, que mineirinho foi morto pela polícia, tendo o cadáver sido transferido depois para outro local para dissimular o assassinato. O caso parece sintetizar de forma exemplar contradições complexas da sociedade brasileira, fruto das vicissitudes do processo de colonização do Brasil, das marcas violentas deixadas pela escravidão, dos desajustes do desenvolvimento capitalista periférico e das políticas elitistas. Não se farão aqui comentários exaustivos do modo de formação político-econômica do Brasil, o que nos desviaria da fatura narrativa do texto e de suas demais implicações. Bastará, para o momento, pressupor a realidade histórica brasileira como pano de fundo da emergência da violência, resultante da tensão entre centro e periferia, desaguando na cena miúda (e cotidiana) de um bandido morto com treze balas. Tal episódio ressoa, a partir das páginas jornalísticas, no interior de um apartamento carioca, na sensibilidade singular da escritora Clarice Lispector. Em entrevista ao jornalista Júlio Lerner, no ano de sua morte, 1977, Lispector comenta o texto sobre mineirinho, um dos que mais gostava. e acrescenta seu repúdio ao excesso de violência policial que envolveu o caso: "uma bala bastava. o resto era vontade de matar". 1 talvez se possa dizer que é esse resto que move sua escrita, isso que excede a ordem da necessidade estrita e transborda os diques que nos contêm. Por que Clarice escreve sobre esse caso, ela que justamente se ressentia de "não saber expressar-se de um modo 'literário' sobre o 'problema social'"? (cf. Borelli, 1981, p.53). ² talvez para escoar também nela esse resto, essa 
sobra, resíduo informe de uma experiência amarga, criando, assim, um leito para um rio turbulento e obscuro, repleto do que desconhecemos.

Desde seu título, "mineirinho", a crônica chama atenção para o uso do diminutivo nos nomes de bandidos, o que tem sido frequente na história da marginalidade brasileira, como Fernandinho beira-mar, escadinha, Marcelinho v.p., todos traficantes que também frequentaram em seu tempo as páginas dos jornais. Esse índice de informalidade é incorporado ao texto, trazendo para o espaço familiar uma personagem perigosamente estranha e alheia ao ambiente doméstico. $O$ traço de afetividade no tratamento infantil é notório e faz de mineirinho alguém a ser adotado pelo autor e por seus leitores. 3 o contraste com o termo "facínora", logo no primeiro parágrafo, mostra que a opção do narrador é opor-se a esse grande outro enigmático e desconhecido, nomeando-o de forma próxima e inofensiva. Assim começa o texto de Clarice:

É, suponho que é em mim, como um dos representantes de nós, que devo procurar por que está doendo à morte de um facínora. e por que é que mais me adianta contar os treze tiros que mataram mineirinho do que os seus crimes. (Lispector, 1964b, p.252).

Desde a primeira linha, então, o eu narrador e nós - todos, incluindo os leitores estamos imersos no mesmo dilema, na mesma procura. O início do texto supõe uma espécie de procuração desse "nós" para o narrador (na verdade "narradora", uma vez que a cronista não oculta que a voz em primeira pessoa seja dela mesma, ainda que seu nome não seja dito em nenhum momento). a frase de abertura indica que é imperioso buscar, pela escrita - "devo procurar" -, um modo de elaborar o acontecimento do mundo exterior. A interioridade se vê atiçada, acuada, pela morte de mineirinho. A presença perturbadora do outro é a mola propulsora do gesto narrativo Clariciano, que não se rende ao fato consumado, desprende-se desse, interioriza a realidade e faz da linguagem espaço de uma consciência indagativa. 4. Esse "outro" provocativo da escritura surge na obra de Lispector sob as mais variadas formas: uma rosa sobre a mesa, um ovo na cozinha, um cego mascando chiclete no ponto do bonde, uma barata no armário, o rosto perdido de uma nordestina. 5Sseja 
como for, em todas essas manifestações da alteridade, o sujeito narrador e o protagonista da trama não podem recuar ante a experiência.

Inevitavelmente transformados por ela, os sujeitos se questionam ao problematizar a exterioridade, perdem-se e se encontram na razão direta com que procuram compreender o outro impossível. A narradora prefere contar os treze tiros que mataram mineirinho do que seus crimes, explorando a duplicidade do verbo "contar" (narrar ou enumerar?). A inversão na pauta literária (paralela à pauta jornalística) se instala de imediato e desloca o foco para o ato de matar um criminoso, embaralhando de vez as fronteiras conhecidas.

Esse trânsito de lugares é mote conhecido da obra Clariciana, exímia em subverter as posições subjetivas dadas como inequívocas. A isso voltaremos mais adiante. O texto prossegue, investigando a ressonância do fato na cozinheira da casa. A reação é assim descrita:

vi no seu rosto a pequena convulsão de um conflito, o malestar de não entender o que se sente, o de precisar trair sensações contraditórias por não saber como harmonizá-las [...] sentir-se dividido na própria perplexidade diante de não poder esquecer que mineirinho era perigoso e já matara demais; e, no entanto nós o queríamos vivo. (ibidem, p.252-3)

Convulsão, mal-estar, contradição, divisão, perplexidade. a sequência traz à tona o que, em princípio, deveria calar-se. Mas nisso reside uma das linhas de força da narrativa Clariciana, que faz da negatividade da experiência humana um território insólito a ser explorado pela linguagem. Como querer vivo um assassino "que já matara demais?". Pela reação de outro (a cozinheira), excluída ela também da cultura dominante, a narrativa põe em discussão olhares diversos e abre espaço para outros valores e crenças, como se vê na resposta da empregada:

\footnotetext{
"o que eu sinto não serve para se dizer. quem não sabe que mineirinho era um criminoso? mas tenho certeza de que ele se salvou e já entrou no céu". Respondi-Ihe que "mais do que muita gente que não matou". (ibidem, p.253)
}

Os índices religiosos presentes na narrativa são numerosos: salvação, céu, escuridão, deus (com maiúscula e depois com minúscula), justiça divina, entre outros. 
na verdade, o próprio texto se estrutura liturgicamente, fazendo da repetição um de seus principais recursos de estilo, como se vê em alguns exemplos:

Meu erro é o meu espelho, onde vejo o que em silêncio eu fiz de um homem. meu erro é o modo como vi a vida se abrir na sua carne e me espantei, e vi a matéria de vida, placenta e sangue, a lama viva. (ibidem, p.254, grifo nosso)

Sua assustada violência. Sua violência inocente - não nas consequências, mas em si inocente como a de um filho de quem o pai não tomou conta. Tudo o que nele foi violência é em nós furtivo... (ibidem, grifo nosso) Frases e palavras voltam como numa reza ou oração, trazendo consigo o peso do sagrado. A crise de uma consciência convulsa se expõe, de um lado, a um confessionário público e, de outro, a uma busca laica pelo sentido do incompreensível. o apelo à lei bíblica é a primeira tentativa de organizar o relato e definir parâmetros:

A primeira lei, a que protege corpo e vidas insubstituíveis, é a de que não matarás. Ela é a minha maior garantia: assim não me matam porque eu não quero morrer, e assim não me deixam matar, porque ter matado será a escuridão para mim. (ibidem, p.253)

O suporte da lei judaico-cristã não garante, no entanto, que tudo se ordene e um resto se impõe, transgredindo e desarticulando a justiça divina. A "vontade de matar" ronda o sexto dos mandamentos e lança o homem a um perigoso abismo. $O$ parágrafo seguinte, que no início afirma a lei para em seguida confrontá-la com a adversativa "mas", mostra que a lei que protege o indivíduo pode por ele ser infringida como modo paradoxal de cumpri-la: Esta é a lei. Mas se há alguma coisa que, se me faz ouvir o primeiro e o segundo tiro com um alívio de segurança, no terceiro me deixa alerta, no quarto desassossegada, o quinto e o sexto me cobrem de vergonha, o sétimo e o oitavo eu ouço com o coração batendo de horror, no nono e no décimo minha boca está trêmula, no décimo primeiro digo em espanto o nome de deus, no décimo segundo chamo meu irmão. O décimo terceiro tiro me assassina - porque eu sou o outro. Porque eu quero ser o outro. (ibidem) 
Aí está à contagem dos treze tiros, anunciada pela cronista na abertura do texto. De certa forma, o modo de apresentação da notícia pelos jornais já trazia o detalhamento das balas em cada uma das partes do corpo atingido. Vale a pena retomar a descrição:

Três tiros nas costas, cinco no pescoço, dois no peito, um no braço esquerdo, outro na axila esquerda e o último na perna esquerda, que estava fraturada, dado à queima-roupa, como prova a calça chamuscada. O retalhamento corporal de mineirinho parece, de fato, ter impressionado nossa autora, que incorpora o recurso dando-lhe um novo destino. A cada tiro a mais, é a sua (e a nossa) escuta que se fere e se contorce de vergonha, de horror, de espanto, culminando na total identificação com a vítima e no seu próprio assassinato.

Do alívio de segurança com o primeiro tiro à morte do outro (e de si) no décimo terceiro, observa-se uma inversão absoluta e crucial: de sujeito protegido pela lei, a narradora se torna o outro perseguido pela mesma lei, dobradiça de duas faces antagônicas. ${ }^{6}$ A gradação que acompanha as frases retoma a sequência jornalística e aproxima novamente os dois discursos, mas com uma nítida diferença: enquanto o jornal promove a total distância entre o eu e o outro, a cronista se transforma no outro. Nesse processo, ela percorre os extremos da proteção e do desamparo, perdendo sua identidade inicial ao se deslocar do campo seguro do si mesmo. Há mesmo um desejo de ser o outro (porque eu quero ser o outro), para assim experimentar-se no limite de uma alteridade. 7

Tendo invertido o ponto de vista pelo qual a violência é agora sentida na própria pele da cronista, todas as demais referências também se alteram. o que antes era segurança e estabilidade passa a sofrer severa crítica por parte da narradora, colocando em xeque não só a justiça que mata mineirinho, mas todo um modo de vida ilusório - porque desidentificado com a nossa mais funda humanidade. é o que se lê no trecho a seguir:

Essa justiça que vela meu sono, eu a repudio, humilhada por precisar dela. Enquanto isso durmo e falsamente me salvo. Nós, os sonsos essenciais. [...] se eu não for sonsa, minha casa estremece. eu devo ter esquecido que embaixo da casa está o terreno, o chão onde nova casa poderia ser erguida. [...] até que treze tiros nos acordam e com horror digo tarde demais - 
vinte e oito anos depois que mineirinho nasceu - que ao homem acuado, que a esse não nos matem. (ibidem, p.253-4)

Treze tiros, 28 anos, oitocentos policiais, oitocentas metralhadoras... O texto de Lispector pontua com números várias passagens reflexivas, trazendo um contraponto interessante. Por que ordenar, de forma tão precisa, o que teima em sair dos limites numéricos? Afinal, trata-se de uma temática existencial, social, humanística, em que não caberia, em princípio, a quantificação. Qual a razão desses marcos? Algumas hipóteses se colocam: tendo nascida de notícias de jornal, a crônica reedita alguns traços próprios da imprensa, como as notações estatísticas e aritméticas (horas e datas, por exemplo), objetivadoras do relato. As manchetes e os trechos jornalísticos reproduzidos páginas antes atestam esse aspecto. A linguagem literária de Clarice flerta com seu rival, o jornal, disfarçando, sob a face pseudocientífica dos algarismos, conteúdos que subvertem as convicções comuns.

Há ainda, porém, outras possibilidades interpretativas desse expediente controlador. As cifras (e a contagem é seu corolário) obedecem a uma normatização universal, abstrata, genérica, enquanto o corpo morto de mineirinho é pura concretude incontável. Essa relação entre corporalidade e numeração aparece, como se sabe, na obra de Sade, que se esmera em organizar suas paixões em classes e modalidades, "obedecendo a um severo princípio de progressão, no qual cada dia é dedicado a exatamente cinco paixões" (cf. Moraes, 2006, p.68). Na análise da obra sadiana cujo estofo de violência e sadismo não é estranho ao texto Clariciano, $\stackrel{8}{8}$. A ensaísta Eliane Robert Moraes (2006, p.68) conclui: A perturbadora aritmética das 120 journées caminha lado a lado com os mais terríveis desregramentos do corpo, como se cada ato físico pudesse ser calculado, contabilizado, enfim, transfigurado em um sinal. Tal é a radicalidade da "filosofia lúbrica" que sade propõe em toda a sua literatura, reconciliando a abstração absoluta das cifras com a irredutível imanência do corpo para recusar a milenar separação entre a ideia e a matéria.

Igualmente radical é a visada clariciana, que justapõe a carne singular à abstração numérica ("abstrato" no sentido de uma despersonalização, quantificação do humano que o desqualifica e o massifica). Também a cronista recusa a separação entre ideia e matéria, buscando entrever na morte de mineirinho, que seria apenas 
uma estatística a mais nas colunas policiais, uma história de abandono familiar e social ("um filho de quem o pai não tomou conta"), uma trajetória desregrada e desviante, de amor e de loucura, que deságua nos treze tiros finais - obsessivamente repetidos nas notícias de jornal e na própria crônica. Novas oposições se acumulam conforme avança o caráter provocador do texto. Contrapõe-se uma justiça a serviço de um sono alienante e falso, que nos salvaria de exercermos revolta e amor, guardados, se estivéssemos acordados. A palavra "sonsa", ${ }^{9}$ que se assemelha a adjetivos como "ingênua" e "ignorante", aponta, sobretudo para aquele que se faz de bobo sem ser. Nesse sentido é que somos todos sonsos, ignorando a violência básica que nos garante dormir em segurança. O sono nos salva porque se estivermos despertos a casa estremece. A imagem se repete e propõe polaridades conhecidas na obra da autora, como se vê no parágrafo que abre o conto "os obedientes":

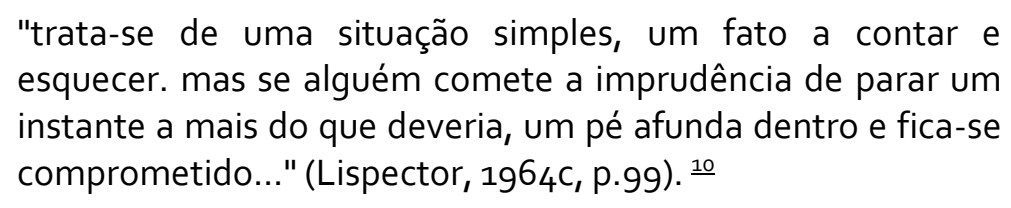

Parar um instante a mais é afundar e se comprometer. O que se "para" talvez seja essa engrenagem automatizam-te - daí sermos todos sonsos - que impossibilita o contato com a tessitura da vida em toda sua intensidade e perigo. Esse seria um dos nós estruturantes da escritura clariciana, uma vez que seus textos querem devassar a morna rotina e suas capas protetoras. Como se descascassem as camadas intermináveis de baratas autômatas e surpreendessem o "de-dentro" delas. 110 embate é mais fundo, se olharmos em perspectiva e abrangência a obra Clariciana. Na constituição do sujeito humano, forças se opõem de forma agônica, estruturando um jogo entre pulsões e defesas.

A proteção contra o mundo explosivo que nos habita constrói a casa e o sono que a narradora rejeita. O dormir perfila, no texto, as formas defensivas que ludibriam nossa incontida agressividade, enquanto o despertar condensa a descarga pulsional: "em mineirinho se rebentou o meu modo de viver" (Lispector, 1964b, p.254), diz a narradora. O recalque da violência, como já se sabe pela teoria psicanalítica, cobra seu preço no processo civilizatório. O que vemos rebentar-se em mineirinho não nos é 
estranho; ao contrário, é demasiadamente humano e por isso "um evita o olhar do outro para não nos entendermos". Mineirinho atualiza o que em cada um de nós é potencialidade aprisionada. Clarice Lispector como sempre, parece colocar à mostra o que deveria ter ficado oculto: a matéria de vida, placenta e sangue, a lama viva. a cadeia significante se estende e prepara a imagem central da crônica - "uma coisa que em nós é tão intensa e límpida como uma grama perigosa de radium", uma espécie de constituinte radical e primária do sujeito que somos. Adiante, a ideia se explicita:

Essa coisa é um grão de vida que se for pisado se transforma em algo ameaçador - em amor pisado; essa coisa, que em mineirinho se tornou punhal, é a mesma que em mim faz com que eu dê água a outro homem, não porque eu tenha água, mas porque, também eu, sei o que é sede... (ibidem, p.255)

Grão de vida, grama de radium. 12 o mundo natural da semente é convocado ao lado de uma força radioativa que, ao ser pisada, explode. A ideia da indeterminação da pulsão parece inequívoca. Haveria uma neutralidade original dessa energia primeva, nem maléfica nem fraterna. o que definiria seus destinos (ou vicissitudes, como quer Freud) destrutivos ou sublimes parece depender de uma multiplicidade de fatores. De todo modo, o que se recalca, segundo a teoria psicanalítica, não é a pulsão propriamente dita, mas seus representantes ideacionais, já que a pulsão ela mesma jamais será abolida e sim deslocada. ${ }^{13}$ a metáfora do radium poderia apontar para esse terreno essencial, potente e neutro, capaz de se dirigir a favor ou contra os próprios homens. Desse manancial, erigimos a mais alta cultura e também a mais violenta destruição.

Ou seja,

o radiumse irradiará de qualquer modo, se não for pela confiança, pela esperança e pelo amor, então miseravelmente pela doente coragem de destruição (ibidem, p.256).

A ideia de uma força vital, informe e indeterminada, substrato humano mais arcaico e fundamento tanto do mal quanto da virtude, assume as mais variadas figurações metafóricas na obra Clariciana. O traço comum em todas elas é sua volatilidade, sua inconsistência material, seu aspecto liquefeito ou energético indefinido. Os textos estão impregnados dessa massa móvel, muitas vezes abjeta, que se encontra na gema do ovo, no chiclete, na massa branca da barata, na geleia viva de uma placenta, entre tantos outros modos de aparição. no texto aqui em questão, soma-se à imagem do radium - que é mais uma das metamorfoses desse núcleo pulsante (pulsional?) - a noção de um perigo iminente, uma ameaça perene que pode pôr tudo a perder. Assim como a casa, armada com os tijolos dos sonsos e da justiça 
que vela nosso sono, é construída sobre o terreno de um radium explosivo, também o texto acaba por se construir sobrepondo sentidos perturbadores. Pode-se dizer que há uma casa/texto se edificando para o leitor, dialetizando com a casa do enunciado textual. O jogo é feito de tal modo que, na contramão de uma "casa sonsa", aparentemente segura e protegida, a narrativa desmonta significações sólidas - na verdade, formações ideológicas que insistem na mitificação de sentidos absolutos e imutáveis - implodindo, por efeitos de linguagem, o mundo imaginário de uma sociedade organizada. A báscula que ordena a crônica propõe oscilações constantes de definições, conceitos, comportamentos, imagens, mostrando que o fora e o dentro, o louco e o são, a ordem e a desordem, a justiça e o crime são dualidades que se relativizam em razão de novos pontos de vista. O texto vive, nos deslizamentos incessantes de suas proposições, o próprio estremecimento que ele anuncia em nossa casa (que "não resistirá à primeira ventania que fará voar pelos ares uma porta trancada"), caso procuremos entender mais do que se deve:

Porque quem entende desorganiza. Há alguma coisa em nós que desorganizaria tudo - uma coisa que entende. [...] essa alguma coisa muito séria em mim fica ainda mais séria diante do homem metralhado. Essa alguma coisa em mim é o assassino em mim? Não, é o desespero em nós. Feito doido nós o conhecemos, a esse homem morto onde à grama de radium se incendiara. Mas só feito doido, e não como sonsos, o conhecemos. (ibidem, p.256)

Entender desorganiza porque implica parar um instante a mais do que se deveria e então um pé afunda dentro... Como a leitura do próprio texto, parada perigosa que nos fulmina com treze tiros, sendo uma ameaça para nosso sono tranquilo. Aliás, organizar/desorganizar é uma das dialéticas fundantes da economia dessa narrativa, chegando a opor uma "maldade organizada" dos homens sãos para se diferenciar da "violência rebentada" em mineirinho. Doidos e sonsos operam, agora, as novas oposições do texto, construindo outro sistema lógico por meio de inversões e tensões. O conhecimento fundo, capaz de desconstruir o arranjo ideológico que nos mantém sonsos, coloca-se, então, ao lado dos doidos. Somente por meio de esse novo olhar, disruptivo e transgressor, será possível habitar uma face inédita do mundo, amar e compreender o que está vedado aos habitantes da frágil casa imaginária. Casa que, como se vê, está posta de cabeça para baixo. 
O pobre leitor se vê agora destituído de um suporte de leis rígidas para estabelecer limites claros entre o eu e o outro, o certo e o errado, a verdade e a falsidade. Nenhum valor pode-se dizer metafísico sustenta-se a essas alturas do texto fora da sua inserção histórica e contextual. Retornamos aqui aos primeiros parágrafos deste ensaio, nos quais se apontou para as mazelas estruturais da história do país. Diante disso, a visão de um homem metralhado se torna porta de acesso tanto para um questionamento da justiça convencional (mata-se um bandido porque assim deve ser), quanto para a miragem de uma justiça outra "justiça prévia" nas palavras do texto, "aquela que vê o homem antes de ele ser um doente do crime". A narração expressa essa nova sensibilidade ancorando-se nas imagens miúdas do corpo inerte de mineirinho: "sem o gorro e sem os sapatos", ou ainda, portando o "São Jorge de ouro e diamantes", índices presentes também nas manchetes dos jornais cariocas. Chama à atenção a dupla face dessa cena: o desamparo de quem perde seus poucos pertences (mas que possuem função identificatória) e a alusão ao santo guerreiro brasileiro, revelando a degradação das imagens religiosas ao longo da crônica. Nem deus, nem deus. Nem gorro, nem sapatos. As imagens vão se esvaziando de qualquer substância que possa garantir uma verdade para além da vacuidade. E no centro desse vazio, a cronista tenta falar por alguém em quem "a fala humana já falhou, ele já é tão mudo que só o grito desarticulado serve de sinalização".

Inevitável associarmos essa mudez e esse grito silenciado a uma das personagens finais da obra Clariciana, Macabéa, protagonista de a hora da estrela. Também ela foi apagada por uma "cidade feita toda contra ela". Periférica e à margem da própria periferia, Macabéa se resguarda na não linguagem, sendo adotada por um narrador que grita por ela. Como diz Lucchesi (1987, p.44), já citado: O silêncio de Macabéa é originário da linguagem ausente, razão por que nada diz e nada é. Macabéa vive sem existir. Está sem jamais ser. Nela não há o que para Sartre é decisivo: a vida como permanente "projeto". Logo, não há possibilidade de a vida ter sentido. Macabéa não existe para o "outro", na razão direta em que não existe para si mesma. Ambas são personagens da exclusão, mas reagem de modos antitéticos. Em mineirinho, a marginalidade se fez violência e terror; em Macabéa, dissolução e desaparecimento de si-mesma. Curiosamente, os treze tiros da crônica surgem 
travestidos em treze títulos do romance, denunciando uma inextricável ligação entre as duas narrativas. $\frac{14}{1}$, aliás, na mesma entrevista já citada, a autora se refere aos dois textos na mesma fala, como se o bandido e a nordestina fossem duas faces - a passiva e a rebelde - de uma mesma moeda nacional. E para estreitar ainda mais o vínculo entre os textos, o narrador interposto no romance, Rodrigo s. m., afirma:

\footnotetext{
"também sei das coisas por estar vivendo. quem vive sabe, mesmo sem saber que sabe. assim é que os senhores sabem mais do que imaginam, e estão fingindo de sonsos" (Lispector, 1993, p.26).
}

Mineirinho reduziu-se ao inumano, bruto e desarticulado. Nele a linguagem, alicerce da constituição do sujeito humano, falhou. A realidade circundante, com sua organizada violência, eliminou mineirinho por um crime de fuzilamento. Mas o que a crônica deixa claro é que, antes mesmo dos treze tiros, o bandido já estava destruído, pisado e perdido como indivíduo. E é para resgatar o homem antes do doente do crime que o texto de Clarice existe. Sua alçada política é inconteste. Para reivindicar uma fala ética, que percebe a humanidade que nos impregna que sabe que "nós todos, lama viva, somos escuros", Clarice Lispector caminha regressivamente para o inumano, para o terreno primordial de onde o homem advém. e a partir dessa mirada regressiva e primal erige-se uma ética da compaixão. se, como diz a autora nos parágrafos finais, "nossa grande luta é a do medo, e que um homem que mata muito é porque teve muito medo", então o perigo reside na nossa fragilidade, na própria insegurança do existir. Todos somos perigosos, porque "na hora de matar um criminoso - nesse instante está sendo morto um inocente".

Cito novamente o ensaio de Berta Waldman (1992, p.161):

Assim, mineirinho mata porque é um pária social, porque sente medo, porque precisa se defender. enquanto a polícia, ao disparar treze tiros contra ele, é assassina e transgride o sexto mandamento que prescreve literalmente 'não assassinarás.

Mineirinho se inocenta ao longo da crônica, passando de criminoso a vítima. por essa inversão final, a autora funda uma ética do humano que, ao contrário dos sonsos 
essenciais, entende que o homem é feito de radium explosivo e que ao deter o mal pode-se também executá-lo. Aporia posta, resta ocupar o silêncio, pelo ato criador da escrita, de quem não pode mais dizer nada.

"o que eu quero é muito mais áspero e mais difícil: quero o terreno."

\section{NOTAS}

1 Entrevista concedida ao jornalista Julio Lerner, da TV Cultura, em janeiro de 1977, publicada quinze anos após sua morte, na Revista Schalom, v.2, n.296, 1992.

$\underline{2}$ Lembremos ainda sua crônica "Literatura e justiça", publicada pela primeira vez em "Fundos de gaveta", segunda parte do volume A legião estrangeira: "Desde que me conheço o fato social teve em mim importância maior do que qualquer outro: em Recife os mocambos foram a primeira verdade para mim. Muito antes de sentir 'arte', senti a beleza profunda da luta. Mas é que tenho um modo simplório de me aproximar do fato social: eu queria era 'fazer alguma coisa', como se escrever não fosse fazer" (Lispector, 1964a, p.149).

3 Agradeço a Eliane Robert Moraes esta entre muitas outras valiosas sugestões ao longo deste ensaio.

4 Ao tratar do romance $A$ hora da estrela, Ivo Lucchesi (1987, p.36) afirma: "A realidade objetiva serve de ponto de partida para a organização da matéria romanesca. Daí em diante a linguagem é o agente operador da transformação em discurso ficcional".

5 Tratam-se dos seguintes textos, na ordem citada: "Imitação da rosa", "O ovo e a galinha", "Amor", A paixão segundo G.H. e A hora da estrela. 
6 Em ensaio sobre o mesmo texto, Berta Waldman (1992, p.159) afirma: "Assim, na visão da narradora. Mineirinho não é culpado, apesar de não ter cumprido a lei. A polícia cumpriu a lei, mas é culpada".

Z Sobre os processos de diferenciação e identificação em Clarice Lispector, remeto o leitor ao ensaio $A$ via-crucis do outro. Identidade e alteridade em Clarice Lispector, de Daniela Mercedes Kahn (2005, p.19), no qual a obra é vista como um território reversível, onde tudo pode se transformar em seu oposto. Conforme a autora, esse universo de relações reversíveis revela que "identidade e alteridade são inseparáveis".

8 Remeto o leitor ao meu estudo Metamorfoses do mal: uma leitura de Clarice Lispector (Rosenbaum, 1999), onde me debruço com maior profundidade sobre as figurações da inveja, da agressividade, do sadismo e das pulsões de morte, tentando abarcar o território da negatividade na obra da autora.

9 Na crônica de Lispector (1991b, p.333), "Das vantagens de ser bobo", de 12 de setembro de 1970, outra ideia de "sonso" aparece na contraposição aos ditos "espertos". Ao lado de mendigos e loucos, os tolos são reverenciados como personalidades de exceção, capazes de se manter à margem de um pensamento hegemônico e massificam-te. A ingenuidade e a disponibilidade para contemplar e viver a vida faz do sonso um tipo resistente ao mundo alienante. Na mesma crônica, os bobos, como a eles se refere a cronista, são aproximados justamente aos habitantes de Minas Gerais, o que nos faz notar que Mineirinho (terá ele nascido em Minas, como quer o epíteto?) se alinha na mesma galeria de ilustres sonsos. Diz o trecho em questão: "Há lugares que facilitam mais as pessoas serem bobas (não confundir bobo com burro, como tolo, com fútil). Minas Gerais, por exemplo, facilita o ser bobo. Ah, quantos perdem por não nascer em Minas!".

10 Também o conto "Amor", de Laços de família, toca na mesma questão: "Expulsa de seus próprios dias, parecia-Ihe que as pessoas da rua eram periclitantes, que se mantinham por um mínimo equilíbrio à tona da escuridão - e por um momento a falta de sentido deixava-as tão livres que elas não sabiam para onde ir" (Lispector, 1991a, p.33). 
11 A substantivação do advérbio é utilizada de forma expressiva no conto "A quinta história", em que uma dona de casa se põe a dedetizar baratas em seu apartamento. A receita da dedetização é assim descrita: "Que misturasse em partes iguais açúcar, farinha e gesso. A farinha e o açúcar as atrairiam, o gesso esturricaria o de-dentro delas. Assim fiz. Morreram" (Lispector, 1964c, p.91).

12 Valeria lembrar aqui o poema "Inocentes do Leblon", de Carlos Drummond de Andrade (1992, p.63), onde o tema é o mesmo: a falsa inocência dos que estão bem de vida e ignoram seu entorno. Até mesmo a referência ao grama de rádio se faz presente: "Os inocentes do Leblon/ não viram o navio entrar./ Trouxe bailarinas?/ trouxe emigrantes?| trouxe um grama de rádio?| Os inocentes, definitivamente inocentes, tudo ignoram./ Mas a areia é quente, e há um óleo suave/ que eles passam nas costas e esquecem". Agradeço a Marcelo Coelho a lembrança do poema.

13 "A disjunção entre uma representação e sua carga afetiva - em outras palavras, o desinvestimento da representação no sistema pré-consciente/consciente - é o essencial do recalque. A pulsão continuará a existir mesmo assim, mas seu movimento deverá encontrar outras saídas. Seus componentes terão destinos separados, mas o cômputo deverá ser o mesmo no final. É o que permite a Freud considerar que, fora de uma satisfação sexual, direta ou indireta, pode haver também uma sublimação, isto é, a energia pulsional dirigir-se a fins não sexuais e socialmente valorizados" (Scarfone, 2004, p.80-1).

14 Agradeço a Jaime Ginzburg a generosidade por compartilhar a sugestão da equivalência do número treze, ideia que lhe foi apresentada por seus alunos durante um curso sobre cultura brasileira em Minessotta (EUA). Relembro ao leitor que o romance $A$ hora da estrela apresenta treze títulos, situando entre eles o próprio nome da escritora. A seguir, alguns exemplos desses: "A culpa é minha" ou "A hora da estrela" ou "Ela que se arranje" ou "O direito ao grito" ou "Clarice Lispector" ou "Quanto ao futuro" ou "Lamento de um blue" ou "Ela não sabe gritar" ou "Uma sensação de perda" ou "Assovio no vento escuro" ou "Eu não posso fazer nada" ou "Registro dos fatos antecedentes" ou "História lacrimogênica de cordel" ou "Saída discreta pela porta dos fundos" (Lispector, 1993, p.23). 


\section{REFERÊNCIAS BIBLIOGRÁFICAS}

ANDRADE, C. D. de. Inocentes do Leblon. In: Poesia e prosa. Rio de Janeiro: Nova Aguilar, 1992.

A hora da estrela. 22. Ed. Rio e Janeiro: Francisco Alves, 1993.

A descoberta do mundo. 3. Ed. Rio de Janeiro: Francisco Alves, 1991b.

BORELLI, O. Esboço para um futuro retrato. Rio de Janeiro: Nova Fronteira, 1981.

KAHN, D. M. A via-crúcis do outro. Identidade e alteridade em Clarice Lispector. São Paulo: FAPESP, Humanistas, 2005.

LISPECTOR, C. Fundo de gaveta. In: A legião estrangeira. Rio de Janeiro: Editora do Autor, 1964 a. p.149.

Mineirinho. In: A legião estrangeira. Rio de Janeiro: Editora do Autor, 1964b. P.252

A legião estrangeira. Rio de Janeiro: Editora do Autor, 1964C.

Amor. In: Laços de família. 24. Ed. Rio de Janeiro: Francisco Alves, 1991 a.

A descoberta do mundo. 3. Ed. Rio de Janeiro: Francisco Alves, 1991b.

LUCCHESI, I. Crise e escritura. Uma leitura de Clarice Lispector e Vergílio Ferreira. Rio de Janeiro: Forense Universitária, 1987.

MORAES, E. R. Lições de Sade. São Paulo: Iluminuras, 2006.

ROSENBAUM, Y. Metamorfoses do mal: uma leitura de Clarice Lispector. São Paulo: Edusp, FAPESP, 1999.

SCARFONE, D. As pulsões. Trad. Paulo Neves. São Leopoldo: Unisinos, 2004.

WALDMAN, B. "Não matarás": um esboço da figuração do "crime" em Clarice Lispector. In: A paixão segundo C.L. São Paulo: Escuta 1992. 
WEGUELIN. J. M. O Rio de Janeiro através dos jornais. S. d. Disponível em: $<$ http://www1.uol.com.br/rionosjornais/rj45.htm

ANEXOS:

Mineirinho

Clarice Lispector

- Como não amá-lo, se ele viveu até o décimo terceiro tiro o que eu dormia?

-... Essa coisa, que em Mineirinho se tornou punhal, é a mesma que em mim faz com que eu dê água a outro homem, não porque eu tenha água, mas porque, também eu, sei o que é sede;

- Quem não sabe que Mineirinho era criminoso? Mas tenho certeza de que ele se salvou e já entrou no céu". Respondi-lhe que "mais do que muita gente que não matou".

É, suponho que é em mim, como um dos representantes do nós, que devo procurar por que está doendo a morte de um facínora. E por que é que mais me adianta contar os treze tiros que mataram Mineirinho do que os seus crimes. Perguntei a minha cozinheira o que pensava sobre o assunto. Vi no seu rosto a pequena convulsão de um conflito, o mal-estar de não entender o que se sente, o de precisar trair sensações contraditórias por não saber como harmonizá-las. Fatos irredutíveis, mas revolta irredutível também, a violenta compaixão da revolta. Sentir-se dividido na própria perplexidade diante de não poder esquecer que Mineirinho era perigoso e já matara demais; e no entanto nós o queríamos vivo. A cozinheira se fechou um pouco, vendo-me talvez como a justiça que se vinga. Com alguma raiva de mim, que estava mexendo na sua alma, respondeu fria: "O que eu sinto não serve para se dizer. Quem não sabe que Mineirinho era criminoso? Mas tenho certeza de que ele se salvou e já entrou no céu". Respondi-lhe que "mais do que muita gente que não matou". 
Por que? No entanto a primeira lei, a que protege corpo e vidas insubstituíveis, é a de que não matarás. Ela é a minha maior garantia: assim não me matam, porque eu não quero morrer, e assim não me deixam matar, porque ter matado será a escuridão para mim.

Esta é a lei. Mas há alguma coisa que, se me faz ouvir o primeiro e o segundo tiro com um alívio de segurança, no terceiro me deixa alerta, no quarto desassossegada, o quinto e o sexto me cobrem de vergonha, o sétimo e o oitavo eu ouço com o coração batendo de horror, no nono e no décimo minha boca está trêmula, no décimo primeiro digo em espanto o nome de Deus, no décimo segundo chamo meu irmão. $O$ décimo terceiro tiro me assassina - porque eu sou o outro. Porque eu quero ser o outro.

Essa justiça que vela meu sono, eu a repudio, humilhada por precisar dela. Enquanto isso durmo e falsamente me salvo. Nós, os sonsos essenciais. Para que minha casa funcione, exijo de mim como primeiro dever que eu seja sonsa, que eu não exerça a minha revolta e o meu amor, guardados. Se eu não for sonsa, minha casa estremece. Eu devo ter esquecido que embaixo da casa está o terreno, o chão onde nova casa poderia ser erguida. Enquanto isso dormimos e falsamente nos salvamos.

Até que treze tiros nos acordam, e com horror digo tarde demais - vinte e oito anos depois que Mineirinho nasceu - que ao homem acuado, que a esse não nos matem. Porque sei que ele é o meu erro. E de uma vida inteira, por Deus, o que se salva às vezes é apenas o erro, e eu sei que não nos salvaremos enquanto nosso erro não nos for precioso. Meu erro é o meu espelho, onde vejo o que em silêncio eu fiz de um homem. Meu erro é o modo como vi a vida se abrir na sua carne e me espantei, e vi a matéria de vida, placenta e sangue, a lama viva.

Em Mineirinho se rebentou o meu modo de viver. Como não amá-lo, se ele viveu até o décimo-terceiro tiro o que eu dormia? Sua assustada violência. Sua violência inocente - não nas consequências, mas em si inocente como a de um filho de quem o pai não tomou conta.

Tudo o que nele foi violência é em nós furtivo, e um evita o olhar do outro para não corrermos o risco de nos entendermos. Para que a casa não estremeça. 
A violência rebentada em Mineirinho que só outra mão de homem, a mão da esperança, pousando sobre sua cabeça aturdida e doente, poderia aplacar e fazer com que seus olhos surpreendidos se erguessem e enfim se enchessem de lágrimas. Só depois que um homem é encontrado inerte no chão, sem o gorro e sem os sapatos, vejo que esqueci de lhe ter dito: também eu. Eu não quero esta casa. Quero uma justiça que tivesse dado chance a uma coisa pura e cheia de desamparo em Mineirinho - essa coisa que move montanhas e é a mesma que o fez gostar "feito doido" de uma mulher, e a mesma que o levou a passar por porta tão estreita que dilacera a nudez; é uma coisa que em nós é tão intensa e límpida como uma grama perigosa de radium, essa coisa é um grão de vida que se for pisado se transforma em algo ameaçador — em amor pisado; essa coisa, que em Mineirinho se tornou punhal, é a mesma que em mim faz com que eu dê água a outro homem, não porque eu tenha água, mas porque, também eu, sei o que é sede; e também eu, que não me perdi, experimentei a perdição.

A justiça prévia, essa não me envergonharia. Já era tempo de, com ironia ou não, sermos mais divinos; se adivinhamos o que seria a bondade de Deus é porque adivinhamos em nós a bondade, aquela que vê o homem antes de ele ser um doente do crime. Continuo, porém, esperando que Deus seja o pai, quando sei que um homem pode ser o pai de outro homem.

E continuo a morar na casa fraca. Essa casa, cuja porta protetora eu tranco tão bem, essa casa não resistirá à primeira ventania que fará voar pelos ares uma porta trancada. Mas ela está de pé, e Mineirinho viveu por mim a raiva, enquanto eu tive calma. Foi fuzilado na sua força desorientada, enquanto um deus fabricado no último instante abençoa às pressas a minha maldade organizada e a minha justiça estupidificada: o que sustenta as paredes de minha casa é a certeza de que sempre me justificarei, meus amigos não me justificarão, mas meus inimigos que são os meus cúmplices, esses me cumprimentarão; o que me sustenta é saber que sempre fabricarei um deus à imagem do que eu precisar para dormir tranquila e que outros furtivamente fingirão que estamos todos certos e que nada há a fazer.

Tudo isso, sim, pois somos os sonsos essenciais, baluartes de alguma coisa. E, sobretudo procurar não entender. Porque quem entende desorganiza. Há alguma coisa em nós que desorganizaria tudo - uma coisa que entende. Essa coisa que fica 
muda diante do homem sem o gorro e sem os sapatos, e para tê-los ele roubou e matou; e fica muda diante do São Jorge de ouro e diamantes. Essa alguma coisa muito séria em mim fica ainda mais séria diante do homem metralhado. Essa alguma coisa é o assassino em mim? Não, é desespero em nós. Feito doidos, nós o conhecemos, a esse homem morto onde a grama de radium se incendiara. Mas só feito doidos, e não como sonsos, o conhecemos. É como doido que entro pela vida que tantas vezes não tem porta, e como doido compreendo o que é perigoso compreender, e só como doido é que sinto o amor profundo, aquele que se confirma quando vejo que o radium se irradiará de qualquer modo, se não for pela confiança, pela esperança e pelo amor, então miseravelmente pela doente coragem de destruição. Se eu não fosse doido, eu seria oitocentos policiais com oitocentas metralhadoras, e esta seria a minha honorabilidade. Até que viesse uma justiça um pouco mais doida. Uma que levasse em conta que todos temos que falar por um homem que se desesperou porque neste a fala humana já falhou, ele já é tão mudo que só o bruto grito desarticulado serve de sinalização.

Uma justiça prévia que se lembrasse de que nossa grande luta é a do medo, e que um homem que mata muito é porque teve muito medo. Sobretudo uma justiça que se olhasse a si própria, e que visse que nós todos, lama viva, somos escuros, e por isso nem mesmo a maldade de um homem pode ser entregue à maldade de outro homem: para que este não possa cometer livre e aprovadamente um crime de fuzilamento.

Uma justiça que não se esqueça de que nós todos somos perigosos, e que na hora em que o justiceiro mata, ele não está mais nos protegendo nem querendo eliminar um criminoso, ele está cometendo o seu crime particular, um longamente guardado. $\mathrm{Na}$ hora de matar um criminoso - nesse instante está sendo morto um inocente. Não, não é que eu queira o sublime, nem as coisas que foram se tornando as palavras que me fazem dormir tranquila, mistura de perdão, de caridade vaga, nós que nos refugiamos no

abstrato.

O que eu quero é muito mais áspero e mais difícil: quero o terreno.

Livro Para não esquecer. São Paulo: Ática, 1979, p. 101, 102, 103. 
i [1] Pós-Doutorado em Educação: Formação de Professores: FCU - Florida Christian University / EUA. Mestrado e Doutorado e Educação: Formação de Professores e Novas Tecnologias. Especialista em Docência do Ensino Superior. Pesquisador no centro de Estudos da Linguagem pela Uniatlantico Espanha. 